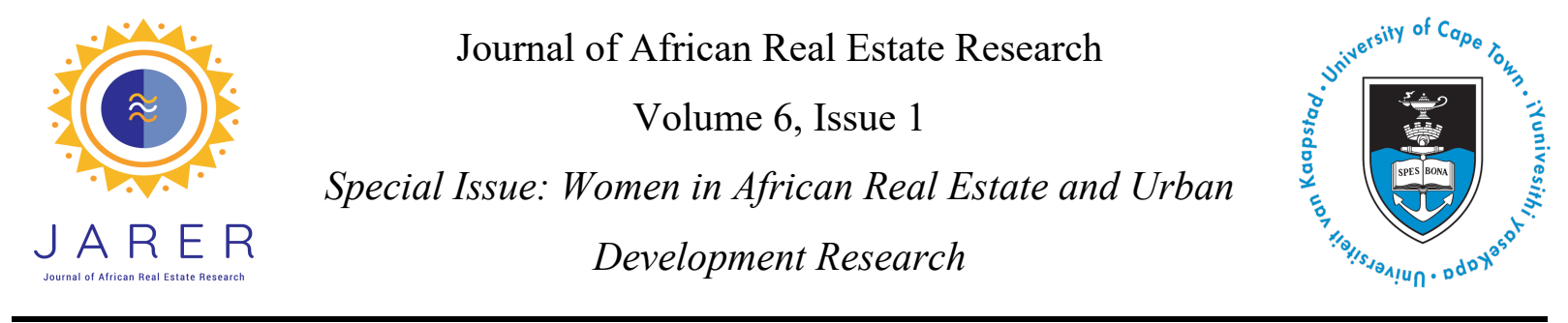

\title{
Approaching Day Zero: Effects of Water Scarcity in Construction Projects in South Africa
}

Thabelo Ramantswana ${ }^{1}$, Phelisa Mdingi ${ }^{2}$, Mandisi Maake ${ }^{3}$ and Peter Vuyani ${ }^{4}$

${ }^{1-4}$ School of Construction Economics and Management, University of the Witwatersrand, South Africa

To cite this article: Ramantswana, T., Mdingi, P., Maake, M. \& Vuyani, P. (2021). Approaching Day Zero: Effects of Water Scarcity in Construction Projects in South Africa. Journal of African Real Estate Research, 6(1), pp.104-120. DOI: 10.15641/jarer.v6i1.976.

\begin{abstract}
Water is a precious resource that is essential for human life and useful for development. This paper explores the effects of water scarcity on the construction industry in the South African context. Primary data were collected using semi-structured interviews in the Western Cape, Gauteng, Mpumalanga and Limpopo Provinces. The study found that construction projects require much water, however, the volume of water usage varies depending on the type and magnitude of the construction project. A lack or scarcity of water can derail projects or bring them to a complete halt. Therefore, construction companies need to take measures to mitigate the effects of water scarcity during their construction projects by factoring water scarcity into their risk assessments. This requires construction companies and their clients to agree on the mitigating factors in case of water scarcity. Project pre-planning is vital to mitigate some of the challenges related to water scarcity. Construction projects requiring a high volume of water need not only rely on water that can be provided through government infrastructure, but should also source water through other means, such as drilling boreholes, recycling, and by applying water saving techniques.
\end{abstract}

Keywords: Climate Change; Drought; Water Scarcity; Construction Projects; Construction Industry; South Africa

\section{Introduction}

Water is a necessity of life and demand for it is ever-increasing across the globe. In recent years, the world has witnessed conflicts over fresh water (Johnson, 2016). The increasing human population and climate change

\footnotetext{
${ }^{1}$ Thabelo.Ramantswana@,wits.ac.za
} 
continuously exacerbate water demand. Therefore, water and water scarcity issues require increased attention in both the public and private arenas.

Water is also a vital resource for construction projects, which consume a substantial amount of water during their life cycles (McCormack et al., 2007; Olsen et al., 2017; Wang et al., 2019; Wu et al., 2019). Construction is one of the main contributors to the South African economy due to its backward and forward linkages to other sectors (Oguntona et al., 2019). However, water scarcity in South Africa could potentially derail the construction industry and property development. The recent droughts and lack of water have resulted in water-shedding in some parts of the country. This paper explores the effects of water scarcity on the construction industry in South Africa, with reference to the following provinces; the Western Cape, Gauteng, Mpumalanga and Limpopo.

This paper is structured as follows: The first section lays the necessary context for the study. The second section comprises the literature review. The third section furnishes the data and analysis, and the last section concludes the paper.

\section{Background of the Study}

Studies suggest that sub-Saharan African countries will face the risk of water stress in the coming decade due to climate change (Arsiso et al., 2017). The effects of climate change are increasingly felt in South Africa through recurring droughts ${ }^{1}$, causing empty or critically low levels of dams and drying boreholes (Calzadilla et al., 2014; Donnenfeld et al., 2018). In Cape Town, water scarcity escalated across 2015-2018, leading to the highly publicised Day Zero, that is, a countdown towards the day when the taps would run dry. Although Cape Town was hit hard, Bischoff-Mattson et al. (2020) argue that Gauteng Province was also just one drought away from devastating water scarcity. Other parts of the country that are prone to drought are Limpopo and the Free State. It stands to reason that a drought-prone country should have developed better coping mechanisms and should have striven to improve its water infrastructure. However, the country is still characterised by poor water infrastructure (Donnenfeld et al., 2018). The recent droughts are once again exposing the poor water infrastructure in the country. This poses a challenge to the South African government to develop a coordinated plan to address water scarcity, which threatens lives, livelihoods, and the development agenda.

The construction industry is among the key driving forces of the socioeconomic development of any nation (Giang \& Pheng, 2011; Durdyev \& Ismail, 2012; Oyewobi et al., 2015). Within the national economy, the construction industry is dynamic, has highly visible output, and can stimulate

\footnotetext{
${ }^{1}$ Since the 1920 drought, the country has observed droughts in 1964, 1980, 1981, 1986, 1988, 1990, 1995, and 2004 2007/2008, and 2015/2016
} 
sizable economic growth (Giang \& Pheng, 2011; Durdyev \& Ismail, 2012). It contributes to shaping socio-economic dynamics by providing infrastructure such as roads, dams, schools, hospitals, railway lines, and bridges. However, water scarcity has the potential to weaken the construction industry, which would have devastating effects on the economy and many livelihoods. Therefore, it is crucial to understand the effects of water scarcity on this industry, especially since this is an under-researched area.

Water is used in multiple stages in the construction process. McCormack et al. (2007) noted that water is used in the extraction, production, and manufacturing of materials as well as during on-site construction. There are two types of water usage in the construction industry, namely embodied water and direct water. Embodied water is the water that is used in the production of construction materials, while direct water (or induced virtual water) is the water that is used at the construction site (Mannan and Al-Ghamdi, 2020).

Embodied water is mainly used in the industrial sector, which supplies construction materials, including steel, cement, and glass. The industrial sector is the second-largest consumer of water in South Africa following the agricultural sector (Gerbens-Leenes et al., 2018). Bardhan (2011) examined the amount of water consumed in the production of construction materials, identifying bricks, cement, aluminium, and glass as the materials that require the most water in their manufacturing processes and concluding that the production of construction materials cannot take place without water. Choudhuri (2015) showed that the production of steel uses more water than the other commonly used building materials such as cement, bricks, aluminium, and clear float glass.

During the construction phase, the use of water varies depending on the project; however, water is typically required for the following activities: temporary site accommodation, general site activities; wet trades; drywall partitions; site dust suppression and cleaning; commissioning; and testing (Waylen et al., 2011). The wet trades include brickwork, mixing of mortar and concrete, curing work, fitting interiors such as bathrooms and kitchen, grout, masonry, painting and decorating, screed, tiling, plastering, soaking materials, and fire protection. Water is also used to establish vegetation on site, flush pipes and test pressure. In addition to the construction activities that use water, water is used for the personal hygiene of employees in toilets and washrooms.

\section{Literature Review}

Water scarcity as an area of research has received attention from sectors such as agriculture, forestry and energy (Rouault \& Richard, 2003; Sheffield et al., 2014; Lesk et al., 2016). The literature suggests that water scarcity affects every aspect of life and every sector of the economy that relies on or uses water. Aigbavboa et al. (2017) and Wu et al. (2019) note that the construction industry is one of the major consumers of water; however, very few works have been published linking it with water scarcity. These few studies focus 
on water-saving techniques within the construction industry (Campisano et al., 2017; Habtemariam et al., 2018; Wanjiru \& Xia, 2018; Wu et al., 2019; Zhao et al., 2018). Moreover, there is an inadequate appreciation of the significance of drought in construction (Hawkins, 2013).

Water scarcity is an external risk factor in construction projects that must be handled properly (Khan \& Gul, 2017). Several studies conclude that external factors will most likely cause delays in construction projects (Assaf \& AlHejji, 2006; Muhwezi et al., 2014). When the construction industry is negatively affected due to water scarcity, then the real estate industry is also affected. Water scarcity may contribute to project delays and poor-quality buildings. It may also cost property investors more when there are delays, cost overruns, and consequent reductions in quality. Studies reveal that cost and time overruns are interrelated in construction projects (Kaliba et al., 2009; Olawale \& Sun, 2010).

Cost, time, and quality are the most common variables against which the success or failure of a project is determined. A project is usually deemed successful when it is delivered at the required quality within the agreed budget and timeframe (Long et al., 2004; Larsen, et al., 2016). Failure to achieve these targets may be due to many factors associated with internal and/or external factors (Khan \& Gul, 2017). Water scarcity or drought falls within the external factors or risks over which the client and contractor have little control.

Some of the problems that cause delays, cost overruns and quality problems may be inevitable in construction projects. Thus, pre-project planning is vital for project performance and success. It is possible to avoid some of the challenges associated with time, cost, and quality through increased preproject planning to reduce risks (Yang et al., 2012; Larsen et al., 2016). Preproject planning may reduce risk, increase quality and improve the chance of success because the contractor is prepared and able to play a proactive role during construction (Larsen et al., 2016). Khan and Gul (2017) suggest that those involved in construction projects should have a contingency plan to deal with some external risks such as water scarcity. In this manner, infrastructure development projects may proceed with minimal disruption, even with water scarcity or a sudden change in the water supply.

Water used in construction comes from multiple sources: stormwater, reusable water from wastewater treatment plants and potable water. Water usage in construction projects varies from country to country, as it is intertwined with local factors such as climate, available water resources and societal attitudes towards water usage (Heravi \& Abdolvand, 2019). In South Africa, the social and cultural resistance to using alternative building materials to brick and mortar exacerbates the extensive use of water in construction (Gunnell et al., 2009). This is still the case, even now, as the country still prefers conventional construction methods and ordinary sources of water (Windapo et al., 2021). South Africa could consider other options, such as desalination, and foster the increased use of groundwater and 
rainwater harvesting. Desalination has been used widely in the Middle East, North Africa (MENA) (Negewo, 2012; Li et al., 2018), Australia (Palmer, 2014; Li et al., 2018) and other countries with extreme freshwater scarcity coupled with rapid population growth. However, it is important to note that water quality may impact the strength of certain types of construction (Wegian, 2010; Meena \& Luhar, 2019); therefore, the water treatment or purification process cannot be undermined. Concrete and mortar require water of a certain quality for strength. The water used in construction must be of good quality and cleaned of foreign substances such as oils, acid, salt, and organic materials. Potable water is recommended for concrete, in particular. Construction projects also require water of a specific standard, which might be difficult to obtain during water scarcity.

Addressing some of the challenges related to water scarcity in the preplanning phase of a construction project will ensure that the project is appropriately planned so that problems are foreseen and mitigated (Heravi et al., 2015; Larsen et al., 2016; Khan \& Gul, 2017). Key role players, including architects, geologists, engineers, project managers, construction managers, and quantity surveyors, can work together in the planning phase of construction for a successful project. They can modify project plans to accommodate the water shortage. During this phase, the stakeholders can make vital decisions related to construction materials that use less water without necessarily compromising quality and consider mitigating actions in case of water scarcity.

\section{Methodology}

This is an exploratory study seeking to understand the effects of water scarcity from the perspective of those involved in construction projects. It takes an interpretivist worldview wherein the respondents report their experience with construction projects. To better understand the experiences of the respondents, the study adopts a qualitative approach. Primary data were garnered from interviews with stakeholders in the construction industry to extract as much information as possible.

The respondents were from the Western Cape, Gauteng, Mpumalanga and Limpopo Provinces. These provinces were purposively selected because they are the most affected by drought and water scarcity. The Western Cape Province has suffered severe droughts, recently in 2015/2016 and 2017/2018, and was approaching Day Zero. Hence, respondents from the Western Cape were useful for the study as they have a long experience with drought, and faced many water restrictions to avoid Day Zero. Gauteng was the only province not declared a disaster province in the 2015/2016 drought and was one of the least affected regions in the 2017/2018 drought, but it was at high risk. Respondents from Gauteng were relevant in the study to supply different views and experiences from those of the respondents from the Western Cape. Both Gauteng and Cape Town city regoins are key economic hubs in South Africa. Limpopo Province is also regarded as being drought-prone, although it suffered minimally in $2017 / 2018$, which means that it likely developed 
coping mechanisms after the 2016/2017 drought experience. Mpumalanga Province is another province that is prone to drought.

The population under study within the provinces includes construction project stakeholders and role-players within the construction industry, namely contractors, project managers, clients (developers), engineers, architects and quantity surveyors. Although the construction contract typically has only two parties (the employer and contractor), several role players are usually involved (appointed separately by either party or in some cases jointly by both parties) who contribute to the construction process.

The respondents are key role players in their companies and are familiar with the importance of water in any construction project. Moreover, these respondents were judged to be able to give meaningful feedback concerning the effects of water scarcity on construction projects. The respondents have extensive experience in construction projects and have been involved in several projects apart from their current ones. This implies that respondents were drawing from their current and past experiences with construction projects in the interviews. It was also established during the interviews that the respondents' location did not pose a limitation to understanding problems in other provinces because they have worked in various projects in different provinces. Table 1 indicates the professional background of the respondents in both the first and second stages of the data collection. The respondents approached the issue of water scarcity from different perspectives based on their professional experience.

Table 1: Location and Professional Background of the Respondents

\begin{tabular}{|c|c|c|c|c|c|c|}
\hline & \multicolumn{6}{|c|}{ Professional Background } \\
\hline \multicolumn{7}{|c|}{ Stage 1} \\
\hline Province & $\begin{array}{l}\text { Quantity } \\
\text { Surveyor }\end{array}$ & Contractor & $\begin{array}{l}\text { Project } \\
\text { Manager }\end{array}$ & Engineer & Architect & Total \\
\hline Gauteng & 5 & 1 & 1 & & & 7 \\
\hline Western Cape & 1 & 1 & 1 & & & 3 \\
\hline Limpopo & & 1 & & & & 1 \\
\hline \multicolumn{7}{|c|}{ Stage 2} \\
\hline Province & $\begin{array}{l}\text { Quantity } \\
\text { Surveyor }\end{array}$ & Contractor & $\begin{array}{l}\text { Project } \\
\text { Manager }\end{array}$ & Engineers & Architect & \\
\hline Gauteng & 4 & 1 & 5 & 3 & 3 & 16 \\
\hline Western Cape & & & & 1 & & 1 \\
\hline Limpopo & & 1 & 3 & 2 & & 6 \\
\hline Mpumalanga & & & 1 & 1 & & 2 \\
\hline Total & 10 & 5 & 11 & 7 & 3 & 36 \\
\hline
\end{tabular}

Most of the respondents are responsible for multiple aspects of construction, especially the contractors and project managers who are architects, engineers or quantity surveyors. The sample was distributed across different professional backgrounds, reflecting opinions from a range of stakeholders 
within the construction industry, although dominated by respondents in Gauteng Province.

Purposive sampling was used to select an initial group of 11 participants. The same approach was subsequently used to select a second group of five participants and thereafter a snowball sampling technique was used to reach 20 additional relevant construction stakeholders. Semi-structured interview questions were used to collect primary data in August-September 2018 and November 2020.

Due to the unavailability of some respondents to participate in face-to-face interviews and the restrictions imposed by the COVID-19 pandemic, online and telephone interviews were also used to gather data. In the first wave, three interviews were conducted with respondents from the Western Cape. Of the three, two were conducted online and one over the telephone. There were seven respondents from Gauteng Province with three face-to-face interviews and four online interviews. There was one online interview with a respondent from Limpopo Province. The second wave of interviews consisted of 25 respondents. Telephone interviews were conducted with both clients and contractors. An architect, two contract managers (a civil engineer and quantity surveyor), and two project managers (a civil engineer and quantity surveyor) were interviewed. These five respondents gave leads to an additional 20 online interviewees. It is important to note that the respondents responded adequately to all the questions asked. There was an opportunity to probe and conduct follow up interviews regarding some questions to obtain clarity and further information. The five telephone interviews were comprehensive, and saturation was reached when no new information emerged from both the telephone and online interviews.

The interview questions were designed to obtain information on the importance of water and its usage; the effects of water scarcity on project timeframes, cost and quality; and the coping mechanisms employed. In the first stage of the interviews the respondents from the Western Cape were asked additional questions about their awareness of the drought before starting projects that were undertaken during the drought season. After the first stage of interviews it was clear that other provinces had also experienced drought or water shortages. As a result, the specific questions that were directed to respondents in the Western Cape were merged with other questions so that all the respondents were asked similar questions. However, this did not affect data credibility, as this study used semi-structured interview questions, enabling the interviewer to probe further. Even in the first stage of the interviews the questions were designed to enable the respondents to give relevant information for this study across provinces.

Thematic analysis was used to analyse data gathered from the interviews. This analytical technique helped identify patterns and themes from the collected data (Maguire \& Delahunt, 2017). The themes identify the major issues relating to water scarcity in construction projects and are used to help understand the effects of water scarcity on construction projects. The analysis 
was not based on the province nor professional background, but rather the emerging themes across the data gathered from the respondents. The process followed was first going through the responses to get a clear understanding of the data received. After this stage, we went back again to try to categorise the information and then extract major themes emerging from the data. Thereafter, some themes were merged after realising that some information belongs to one theme. Then, we undertook the write-up stage but continued going back and forth between write-up and further reviewing the data to ensure that important information was not omitted.

\section{Analysis}

\subsection{Importance and usage of water in construction projects}

All the respondents agreed that water is vital to the construction industry. They could not see any construction project running well without water on site. One of the respondents drew an analogy likening water in a construction project with oil in machinery. Although water is important in construction projects, the usage varies depending on the project. For instance, water needed in the construction of buildings is not the same as the water needed in road construction or water reticulation and reservoir construction. Water usage also varies depending on the stage and type of project. Some projects require less water during the initial stages but require more water in the final stages. The construction of buildings uses less water than road construction. However, those involved in water reticulation and reservoir projects said that these types of projects do not require much water during the early stages of construction but need much more towards the end. Water usage also varies, for instance, in the production of concrete, mixing mortar, plastering; site establishment; fire sprinklers; cleaning; stabilisation and compaction of road layers; dust suppression; testing; human consumption, toilet facilities, and for general hygiene on-site.

\subsection{Responsibility for water provision}

Another issue raised concerning the importance of water is the need to discuss who is responsible for water provision at the outset. This is the type of discussion that can take place between the clients and the contractors to avoid disputes. In this manner, the agreement is embedded in the contract. The respondents representing the client said that this information forms part of the tender briefing and the document prepared by the professional team. If there are changes during the construction process in terms of water sources or provision, the respondents said that a variation order is used for the client to pay for the additional cost of water. The respondents representing the contractors argued that this is not always the case because they end up incurring the costs rather than the client.

When water is scarce, both the contractor and the client are affected. Construction may come to a standstill. One respondent in Gauteng put it in a simple way, "no water, no construction"; however, all but three respondents 
said some projects can be completed without water. Some respondents reported that if they run out of water, it must be imported to the site, which increased the cost, thus impacting the project schedule. Water shortages onsite and importing water to the site can result in extra claims for an extension. The client may have to inject more money into the project to accommodate the additional water costs. Sometimes the contractor incurs costs related to water shortages on-site as they take full responsibility to complete the project. In some situations, projects are delayed or postponed until there is water on site. The quality of work is compromised on some projects as the contractor tries to complete the project with less water.

The construction industry is well aware that South Africa is a drought-prone country; nonetheless, it remains difficult to measure the magnitude of the risk of drought when tendering or starting a construction project. Some more significant projects may be suspended because they need more water, and it can be expensive to transport water to the site. In some instances, the budget will be increased to allow for water tankers. Projects that require less water are easier to manage when water scarcity is prevalent and respondents said that it is easier to bring water to the site. The contractors said that depending on the amount of water needed, they weigh up all options and choose the most favourable one. Whichever option they choose, the likelihood of increasing costs and delays is high and can affect the quality of the deliverable. One respondent hinted that this may result in job losses, probably when the additional costs of water are paid by the contractors and were not initially factored into the budget.

\subsection{Areas that are prone to water scarcity}

Although the country is drought-prone, certain areas and cities are at greater risk than others. Construction companies do not shy away from tendering in high-risk areas. Instead, they "incorporate the additional costs and programme implications", according to one of the respondents who completed more than 70 roads and water projects in Limpopo and Mpumalanga Provinces as a consultant, contract manager and engineer. However, one respondent said that there are projects that he decides not to tender for based on the assessment he makes relating to resources and the amount of water that might be needed. The respondents believe that Limpopo was, by far, at the top of the list of provinces that tend to be affected by water shortages. This was surprising because the media focused more on Western Cape as the province most affected by drought. Limpopo was followed by the Western Cape, Eastern Cape, Northern Cape, Free State, Gauteng, Mpumalanga and Kwazulu Natal.

\subsection{Plan and undertake risk assessment}

The planning stage is crucial in construction projects. Knowing which provinces are prone to drought helps the contractors when they tender for projects. Respondents shared several views on what they can do in the planning stage to better prepare for water shortages. Companies can estimate 
the volume of water needed for the project in relation to the supply in the area; they can set aside funds to pay for water tankers at the outset, and they can provide boreholes and purification on site with adequate stored water reserves. Besides, a risk assessment that includes drought and water scarcity should be undertaken before the start of the project. One respondent said that:

"All plans should incorporate how projects are impacted in the event of shortages. Understanding the impacts is vital, and good risk management systems should be established and implemented. Mitigating mechanisms should be incorporated detailing how water would be sourced in the event of shortages."

- Respondent architect who is also a project manager based in Gauteng

\subsection{Coping mechanism for water shortages}

There is a difference between planning and execution; therefore, project managers must play a proactive role throughout the life of the project to attend to issues as they arise. The respondents were asked about measures that may be implemented to deal with water shortages in the execution phase. If the project has not started, sometimes they delay the start date to avoid costs related to drought or water shortages. In many instances, construction projects are affected by drought while in progress. Most of the respondents suggested using water sustainably and tapping into other alternative water sources for their construction projects. The suggestions imply that construction companies should be willing to invest in their employees by providing training in what to do in case of water scarcity. At the same time, they should be prepared to provide what is necessary for the project to continue as planned.

Water shortages force professionals in the construction industry to think of alternative construction methods. For some respondents, this is a call for using resources wisely and embracing greening and sustainability concepts. It is also a call to think carefully about the selection of materials and water consumption levels even after construction. In the design stage, engineers and architects can design structures that require less water. Some respondents suggested the use of alternative construction methods to cope with water scarcity within the construction industry. It was clear from the respondents who are involved in road construction that it is easy to employ alternative construction methods for buildings but more difficult for road construction.

\section{Discussion}

Water scarcity is a global challenge that individuals, industries, and the public and private sectors must find ways to manage. This problem is further intensified by the increase in population and their growing water needs. People need water for their survival, and at the same time, more water is required for agriculture to lessen food insecurity and for infrastructure development. All the respondents in this study agreed that water is essential in construction in line with the findings in the literature (Larsen et al., 2016; 
Wang et al., 2019; Wu et al., 2019; Mannan \& Al-Ghamdi, 2020). The projections in South Africa are not promising in terms of water resources and the infrastructure of the nation. Therefore, the construction industry, which relies heavily on water, must find ways to continue operating with less water.

According to Windapo et al. (2021), the government, builders and occupiers in South Africa still prefer bricks and mortar. The engineers and architects interviewed for this study raised the issue of alternative methods. Thinking of designs and other alternatives for using less water calls for creativity at different levels by those involved in construction projects so that they can find ways to continue delivering the much-needed infrastructure. It was also noted in the data drawn from interviews that engineers thought of a long-term solution of drilling boreholes on-site while quantity surveyors were more focused on finding ways to recycle water on site. In addition, the strategies that quantity surveyors proposed were saving costs and avoiding delays. For the engineers, the strategies were focused on quality and avoiding delays in project timelines. The project managers were more worried about the delay. However, most of the project managers are also engineers, quantity surveyors or architects. Previous literature also concluded that external factors such as water scarcity can cause cost overruns, compromised quality and delays in construction projects (Kaliba et al., 2009; Olawale \& Sun, 2010; Muhwezi et al., 2014).

To avoid some of the challenges, construction industry participants must plan, organise, manage, and execute project activities from start to finish. In this process, they can identify certain challenges concerning the use of water in the project. Yang et al. (2012), Heravi et al. (2015) and Larsen et al. (2016) noted that some issues relating to water shortages could be highlighted in the pre-planning and planning stage. It is up to the construction key role players to advise their clients about the risks involved with water shortages on site. In the planning stage, both parties can devise a plan regarding the sourcing of water and the quantity needed as well as the frequency and cost of delivery. It was clear from the interviews that water shortages at construction sites exert adverse effects on construction projects, resulting in scrutiny of the project's success. In addition, water scarcity may affect the overall cost of a project. This is similar to the findings by Waidyasekara et al. (2013). This finding is also in line with the argument put forward that any delays in construction projects will likely have cost implications for both the contractor and the client (Kaliba et al., 2009; Olawale \& Sun, 2010). Some of the problems relating to water scarcity can be resolved before the project starts if there is proper pre-project planning, as discussed in Larsen et al. (2016). Client representatives can manage the expectations of clients when it comes to cost, time, and quality. Because of the influence of climate change in South Africa, construction contracts should include a risk plan dealing with water shortages and a contingency amount for any additional cost that could arise owing to a water shortage.

South Africa has experienced extreme weather events in recent years, specifically drought, heavy rain leading to flash flooding, severe 
thunderstorms (including hail), bush fires, and strong winds. Projections indicate that the country may continue to experience more extreme weather patterns. Although there are studies focused on these drought-prone areas or cities (Rouault \& Richard, 2003; Sheffield et al., 2014; Lesk et al., 2016), the construction industry should undertake further research to understand the implications for the industry. The onus falls on the industry to initiate these discussions and implement risk mitigation strategies to reduce threats to project objectives. Moreover, contractors should be encouraged to start using other methods, for example, groundwater for construction activities and other innovative techniques, to conserve water resources and reduce their dependence on potable water. Moreover, the use of alternative construction materials should be encouraged. This includes the use of dry technology, precast concrete structures, and specific innovative materials. The construction industry should also draw from the experiences of other countries and strategies to manage water scarcity.

It was evident from the interviews that water shortages in construction projects affect both the contractor and the client. Considering the necessity and usage of water in the production of construction materials during and after the construction phase, it is essential for those involved in the different stages to have clear projections for their water needs and plan accordingly. Property developers need to possess a better understanding of the water situation in the areas in which they are operating. It is crucial to undertake an environmental impact assessment or risk assessment to identify some of these water-related issues beforehand and plan accordingly. The design of buildings and other infrastructure in water-scarce areas should be water efficient. In addition, those involved in the early stages of design and construction should think beyond the construction project. One respondent noted that in drought-prone areas, the client is better off procuring water storage for both construction and post-construction. Having water on-site would be important for managers and occupiers of facilities after completing the project; hence the challenges of water scarcity extends beyond the construction industry. This indicates that whatever is done in the design and construction stages has implications for the subsequent use, management and maintenance of buildings.

\section{Conclusion}

This was an exploratory study of the effect of water scarcity on construction projects. It is an essential study for real estate because of the interdependency and interrelationship of real estate with the construction industry. Although the respondents were located in only four provinces (Western Cape, Gauteng, Limpopo and Mpumalanga), their experience with different types of construction projects in multiple provinces provided them with a holistic view of the effects of water scarcity across most provinces in South Africa.

The study shows that industry participants recognise that water is essential in construction projects and that water scarcity may lead to project delays, cost overruns and compromised quality. The interview data illustrated that the 
volume of water needed varies depending on the nature of the construction projects. Water scarcity affects construction projects to varying degrees, depending on the volume and usage and the ability to source water efficiently. Construction projects requiring high volumes of water need not only rely on water that can be provided through government infrastructure but should also source water through various other means such as drilling boreholes, recycling, and by applying water saving techniques. Furthermore, the results suggest that responsibility for water provision should be embedded in the project agreement to avoid disputes. We also caution developers and contractors to ensure that feasibility studies and risk assessment are completed before commencing a project.

The following areas require further research: first, more research is required to expand knowledge about the role of water and its scarcity in real estate development and operations. Second, considering the varying degrees of water usage in construction projects, it may be useful to undertake research on water scarcity effects focusing on specific construction projects, and to explore alternative construction technologies that use less water. Third, there is need for in-depth analysis of the volume of water used at various stages of construction projects; however, such research would require proper classification of construction projects in order to develop comparable analysis.

Water scarcity is a phenomenon that is to some extent due to factors that are beyond human control; however, this does not absolve us from taking the necessary measures to avert Day Zero in many parts of the country. Developing proper infrastructure to capture, conserve, and distribute water resources is key, as well as laying the foundations for the responsible usage of scarce water across South Africa. Therefore, those in the construction industry have a duty to explore mechanisms that use less water without compromising the quality of the work. Measures may be taken to avoid Day Zero; however, we also rely on the help of Mother Nature to be generous in supplying water. In some parts of the country, such as Nelson Mandela Bay, there are areas that have already passed Day Zero, and this will have negative effects on the construction industry, which relies on water.

\section{References}

Aigbavboa, C., Ohiomah, I. \& Zwane, T. (2017). Sustainable Construction Practices: "A Lazy View" of Construction Professionals in the South Africa Construction Industry. Energy Procedia, 105, pp.3003-3010.

Arsiso, B.K., Tsidu, G.M., Stoffberg, G.H. \& Tadesse, T. (2017). Climate Change and Population Growth Impacts on Surface Water Supply and Demand of Addis Ababa, Ethiopia. Climate Risk Management, 18, pp.21-33.

Assaf, S.A. \& Al-Hejji, S. (2006). Causes of Delay in Large Construction Projects. International Journal of Project Management, 24(4), pp.349-357. 
Bardhan, S. (2011). Assessment of Water Resource Consumption in Building Construction in India. WIT Trans. Ecology and the Environment, 144, pp.93-101.

Bischoff-Mattson, Z., Maree, G., Vogel, C., Lynch, A., Olivier, D. \& Terblanche, D. (2020). Shape of a Water Crisis: Practitioner Perspectives on Urban Water Scarcity and 'Day Zero'in South Africa. Water Policy, 22(2), pp.93-210.

Calzadilla, A., Zhu, T., Rehdanz, K., Tol, R.S. \& Ringler, C. (2014). Climate Change and Agriculture: Impacts and Adaptation Options in South Africa. Water Resources and Economics, 5, pp.24-48.

Campisano, A., D’Amico, G. \& Modica, C. (2017). Water Saving and Cost Analysis of Large-Scale Implementation of Domestic Rain Water Harvesting in Minor Mediterranean Islands. Water, 9(12), pp.1-14.

Choudhuri, I.R. (2015). Assessment of Embodied Water of Construction: Case Study of a Four Star Rated Hotel in New Delhi, India. International Journal of Engineering Research and Technology, 3(8), pp.195-199.

Donnenfeld, Z., Crookes, C. \& Hedden, S. (2018). A delicate Balance: Water Scarcity in South Africa. ISS Southern Africa Report, 2018(13), pp.124.

Durdyev, S. \& Ismail, S. (2012). Role of the Construction Industry in Economic Development of Turkmenistan. Changes, 29(2), pp.883890.

Gerbens-Leenes, P.W., Hoekstra, A.Y. \& Bosman, R. (2018). The Blue and Grey Water Footprint of Construction Materials: Steel, Cement and Glass. Water Resources and Industry, 19, pp.1-12.

Giang, D.T. \& Pheng, L.S. (2011). Role of Construction in Economic Development: Review of Key Concepts in the Past 40 Years. Habitat International, 35(1), pp.118 - 125.

Gunnell, K., Du Plessis, C. \& Gibberd, J. (2009). Green Building in South Africa: Emerging Trends. Department of Environmental Affairs and Tourism (DEAT), pp.1-21.

Habtemariam, L.W., Herslund, L.B. \& Mguni, P. (2018). What Makes a Champion for More Sustainable Urban Water Management in Addis Ababa? Sustainable Cities and Society, 46(101378), pp.1-7.

Hawkins, A.B. (2013). Some Engineering Geological Effects of Drought: Examples from the UK. Bulletin of Engineering Geology and Environment, 72(1), pp.37-59.

Heravi, A., Coffey, V. \& Trigunarsyah, B. (2015). Evaluating the Level of Stakeholder Involvement During the Project Planning Processes of Building Projects. International Journal of Project Management, 33(5), pp.985-997.

Heravi, G. \& Abdolvand, M.M. (2019). Assessment of Water Consumption During Production of Material and Construction Phases of Residential Building Projects. Sustainable Cities and Society, 51(101785), pp.113.

Johnson, H., South, N. \& Walters, R. (2016). The Commodification and Exploitation of Fresh Water: Property, Human Rights and Green 
Criminology. International Journal of Law, Crime and Justice, 44, pp.146-162.

Kaliba, C., Muya, M. \& Mumba, K. (2009). Cost Escalation and Schedule Delays in Road Construction Projects in Zambia. International Journal of Project Management, 27(5), pp.522-531.

Khan, R.A. \& Gul, W. (2017). Empirical Study of Critical Risk Factors Causing Delays in Construction Projects. In proceedings of the 9th IEEE International Conference on Intelligent Data Acquisition and Advanced Computing Systems: Technology and Applications (IDAACS), Vol. 2. IEEE. pp. 900-906.

Larsen, J.K., Shen, G.Q., Lindhard, S.M. \& Brunoe, T.D. (2016). Factors Affecting Schedule Delay, Cost Overrun, and Quality Level in Public Construction Projects. Journal of Management in Engineering, 32(1): 04015032, pp.1-10.

Lesk, C., Rowhani, P. \& Ramankutty, N. (2016). Influence of Extreme Weather Disasters on Global Crop Production. Nature, 529(7584), pp.84-87.

Li, Z., Siddiqi, A., Anadon, L.D. \& Narayanamurti, V. (2018). Towards sustainability in water-energy nexus: Ocean energy for seawater desalination. Renewable and Sustainable Energy Reviews, 82, pp.3833-3847.

Long, N.D., Ogunlana, S., Quang, T. \& Lam, K.C. (2004). Large Construction Projects In Developing Countries: A Case Study from Vietnam. International Journal of Project Management, 22(7), pp.553-561.

Maguire, M. \& Delahunt, B. (2017). Doing a Thematic Analysis: A practical, Step-by-Step Guide for Learning and Teaching Scholars. All Ireland Journal of Higher Education, 9(3), pp.3351- 33514

Mannan, M. \& Al-Ghamdi, S.G. (2020). Environmental Impact of Water-Use in Buildings: Latest Developments from a Life-Cycle Assessment Perspective. Journal of Environmental Management, 261(110198), pp.1-12.

McCormack, M., Treloar, G.J., Palmowski, L., \& Crawford, R. (2007). Modelling Direct and Indirect Water Requirements of Construction. Building Research \& Information, 35(2), pp.156-162.

Meena, K. \& Luhar, S. (2019). Effect of Wastewater on Properties of Concrete. Journal of Building Engineering, 21, pp.106-112.

Muhwezi, L., Acai, J. \& Otim, G. (2014). An Assessment of the Factors Causing Delays on Building Construction Projects in Uganda. International Journal of Construction Engineering and Management, 3(1), pp.13-23.

Negewo, B.D. (ed). (2012). Renewable Energy Desalination: An Emerging Solution to Close the Water Gap in the Middle East and North Africa. Washington, DC: World Bank Publications.

Oguntona, O.A., Akinradewo, O.I., Ramorwalo, D.L., Aigbavboa, C.O. \& Thwala, W.D. (2019). Benefits and Drivers of Implementing Green Building Projects in South Africa. Journal of Physics: Conference Series, 1378(3), pp.1-10. 
Olawale, Y.A., \& Sun, M. (2010). Cost and Time Control of Construction Projects: Inhibiting Factors and Mitigating Measures in Practice. Construction Management and Economics, 28(5), pp.509-526.

Olsen, C., Kowalewski, A., Gould, M., \& Lambrinos, J. (2017). Evaluating Two Rainwater Harvesting Systems in an Urban Setting in Oregon's Willamette Valley. Journal of Green Building, 12(1), pp.1-10.

Oyewobi, L.O., Windapo, A.O. \& James, R.O.B. (2015). An Empirical Analysis Of Construction Organizations' Competitive Strategies and Performance. Built Environment Project and Asset Management, 5(4), pp.417-431.

Palmer, N. (2014). Why We Need Seawater Desalination Plant. Australia National Center of Excellence in Desalination.

Rouault, M. \& Richard, Y. (2003). Intensity and Spatial Extension of Drought in South Africa at Different Time Scales. Water South Africa, 29(4), pp.489-500.

Sheffield, J., Wood, E.F., Chaney, N., Guan, K., Sadri, S., Yuan, X., Olang, L., Amani, A., Ali, A., Demuth, S. \& Ogallo, L. (2014). A Drought Monitoring and Forecasting System for Sub-Sahara African Water Resources and Food Security. Bulletin of the American Meteorological Society, 95(6), pp.861-882.

Waidyasekara K.G.A.S., De Silva M.L. \& Rameezdeen, R. (2013). Comparative Study of Green Building Rating Systems: In Terms of Water Efficiency and Conservation. In proceedings of the International Conference on Socio-economic Sustainability in Construction: Practice, Policy and Research. Colombo, Sri Lanka, 14-15 th June, 2013. pp.108-117.

Wang, J., Shen, L., Ren, Y., Ochoa, J. J., Guo, Z. \& Yan, H. (2019). A Lessons Mining System for Searching References to Support Decision Making Towards Sustainable Urbanization. Journal of Cleaner Production, 209, pp.451-460.

Wanjiru, E. \& Xia, X. (2018). Sustainable Energy-Water Management for Residential Houses With Optimal Integrated Grey and Rain Water Recycling. Journal of Cleaner Production, 170, pp.1151-1166.

Waylen C., Thornback J. \& Garrett, J. (2011). An Action Plan for Reducing Water Usage On Construction Sites. [Online]. Available at: http://docplayer.net/25426695-An-action-plan-for-reducing-waterusage-on-construction-sites.html. Accessed on: 17 $7^{\text {th }}$ June, 2021.

Windapo, A.O, Omopariola, E.D., Olugboyega, O. \& Moghayedi, A. (2021). Use and Performance of Conventional and Sustainable Building Technologies in Low-Income Housing. Sustainable Cities and Society, 65(102605), pp.1-12.

Wegian, F.M. (2010). Effect of Seawater for Mixing and Curing on Structural Concrete. The IES Journal Part A: Civil \& Structural Engineering, 3(4), pp.235-243.

Wu, Z., Wu, Z., Li, H., Zhang, X. \& Jiang, M. (2019). Developing a Strategic Framework for Adopting Water-Saving Measures in Construction Projects. Environmental Geochemistry and Health, 42(3), pp.955968. 
Yang, L.R., Chen, J.H. \& Huang, C.F. (2012). Requirements Definition and Management Practice to Improve Project Outcomes. Journal of Civil Engineering and Management, 18(1), pp.114-124.

Zhao, J.H., Xie, X., Liu, R.B., Sun, Y., Wu, M.K. \& Gu, J.H. (2018). Water and Energy Saving Potential by Adopting Pressure-Reducing Measures in High-Rise Building: A Case Analysis. Building Services Engineering Research \& Technology, 39(5), pp.505-517. 